\title{
Working
}

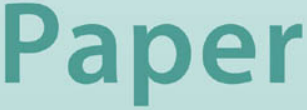




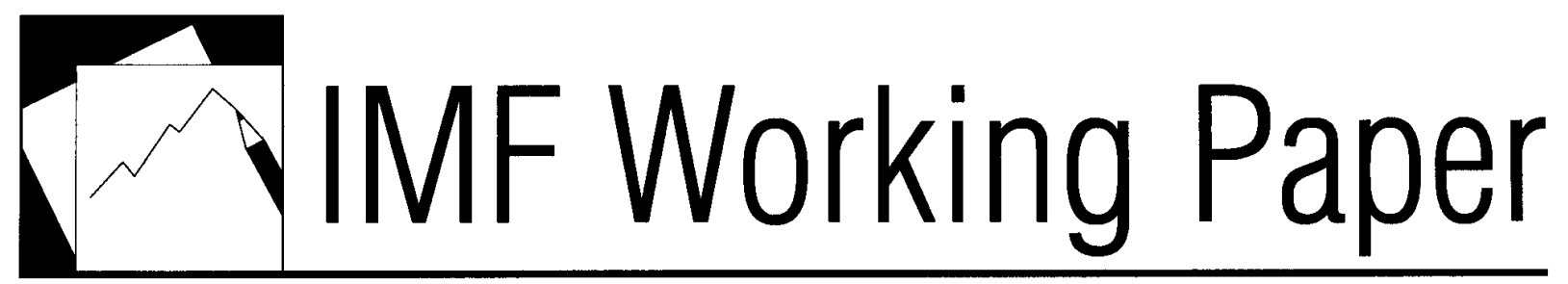

\section{Assessing the Risks to the Japanese Government Bond (JGB) Market}

Waikei Raphael Lam and Kiichi Tokuoka 


\title{
IMF Working Paper
}

Asia and Pacific Department

\section{Assessing the Risks to the Japanese Government Bond (JGB) Market \\ Prepared by Waikei Raphael Lam and Kiichi Tokuoka \\ Authorized for distribution by Kenneth Kang}

December 2011

\section{This Working Paper should not be reported as representing the views of the IMF.}

The views expressed in this Working Paper are those of the author(s) and do not necessarily represent those of the IMF or IMF policy. Working Papers describe research in progress by the author(s) and are published to elicit comments and to further debate.

\begin{abstract}
Despite the rise in public debt, Japanese Government Bond (JGB) yields have remained low and stable, supported by steady inflows from the household and corporate sectors, high domestic ownership of JGBs, and safe-haven flows from heightened sovereign risks in Europe. Over time, however, the market's capacity to absorb new debt will likely shrink as population ages and risk appetite recovers. In the short term, a decline in fund supply from the corporate sector, where financial surpluses are abnormally high, and spillovers from global financial distress could push up JGB yields. Fiscal reforms to reduce public debt more quickly and lengthen the maturity of government bonds will help limit these risks.
\end{abstract}

JEL Classification Numbers: E62

Keywords: Fiscal Sustainability, Sovereign Risk, Government yields, Financial Distress Author's E-Mail Address: WLam@imf.org; KTokuoka@imf.org 


\section{Table of Contents}

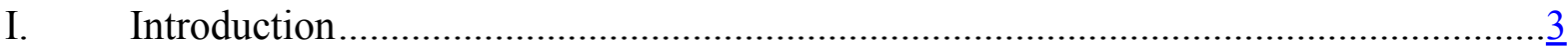

II. Risks to the JGB Market from Shrinking Fund Supply, Global Spillovers, and Market Volatility ...................................................................................................

III. Risks from a Rise in JGB Yields …………………...........................................

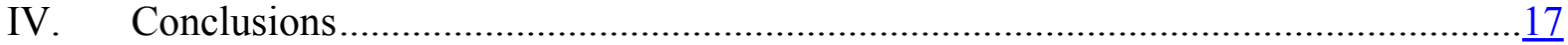

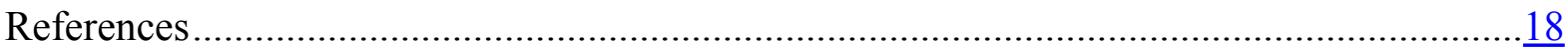

Tables

1. Impact of Loans and Deposits on Banks' Holdings of Government Securities ............. 8

2. Correlation of Japanese Sovereign Yields ..........................................................12

$3 \quad$ Factors Influencing Short-term JGB Yield Movements ............................................14

4. Financial Indicators Influencing Sovereign Risk ......................................................

Figures

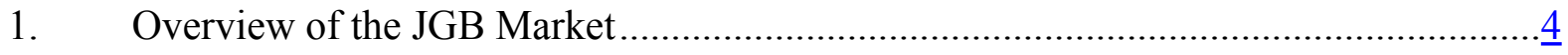

2. Japan: Financial Balance Sheets of the Non-financial Sectors ...................................

3. Fund Supply and Demand of Non-financial Sectors ……..........................................

4. Global Spillovers and Volatility of the JGB Market …………………………..........13 


\section{INTRODUCTION}

Despite the rise in gross public debt to over 200 percent of GDP, yields on JGBs have remained low and stable. After the earthquake in March 2011, despite expectations of additional JGBs to finance reconstruction, 10-year JGB yields have remained around 1.0-1.2 percent. Auctions since the earthquake have been met with steady demand across all key maturities, from banks which continue to purchase short-term securities to life insurers looking to lengthen the duration of their bond portfolios to match their liabilities (Figure 1).

Nevertheless, over the medium term, the market's capacity to absorb new debt is likely to diminish as the population ages and risk appetite recovers. Japan's large pool of domestic savings, stable investor base, and high share of domestic ownership of JGBs have helped maintain stability in the JGB market. But these favorable factors are likely to diminish over time as population aging reduces household saving and risk appetite recovers. Without a significant policy adjustment, the stock of gross public debt could exceed household financial assets in around 10 years, at which point domestic financing may become more difficult. ${ }^{1}$

In the near term, the JGB market also faces domestic and external risks. Domestically, the supply of funds for financing JGBs could decline as private spending to repair the earthquake's damage picks up. An increase in market volatility could also push banks to shorten the maturity of their JGB holdings or reduce their JGB exposures to limit losses. Given the high correlation between yields on JGBs and other sovereign debts, a sudden rise in global risk premia could spillover and affect the JGB market. All these factors could eventually contribute to a sustained rise in yields, worsen the public debt dynamics, and pose a risk to financial stability.

\section{To assess the risks to the JGB market, this paper examines:}

- What are the key risks to stability in the JGB market? What are the possible channels through which a domestic shock or global financial distress could affect the JGB market?

- What would be the implications of sustained high interest rates for public debt dynamics and financial stability? What should be the policy priority to mitigate the risks to the JGB market?

\footnotetext{
${ }^{1}$ See Tokuoka (2010).
} 
Figure 1. Overview of the JGB Market

Despite the rise in public debt, JGB yields have declined and remained low.

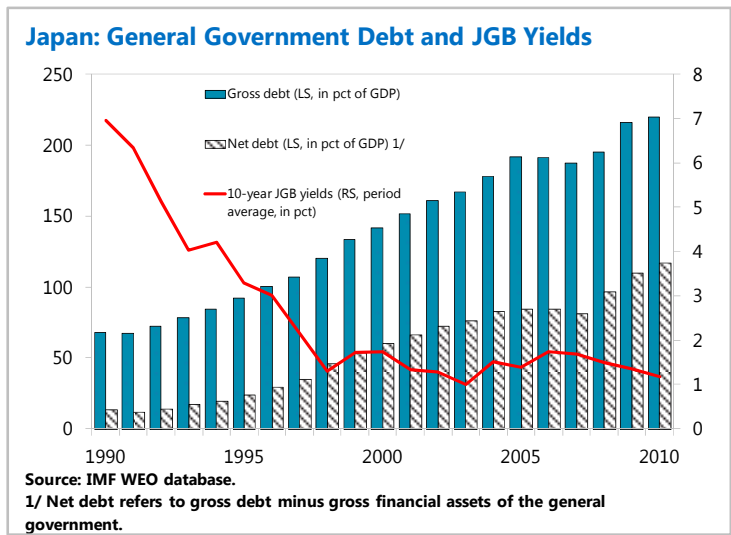

...amid steady demand as shown by recent auction results.

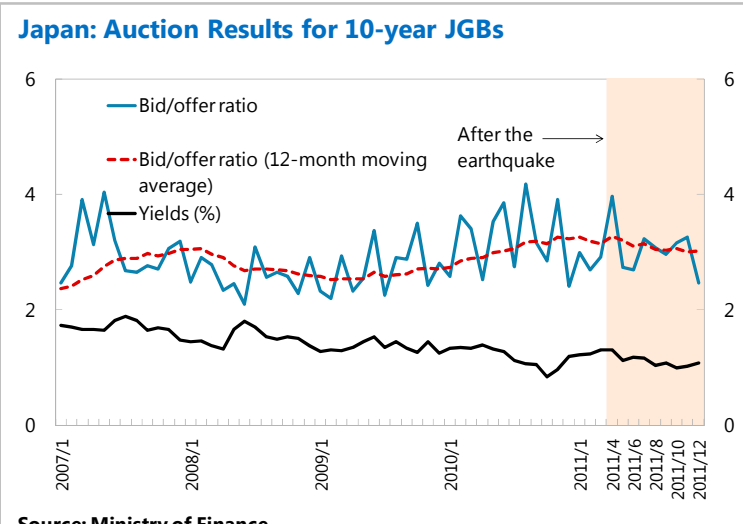

Source: Ministry of Finance.

....and the market has been supported by stable domestic players..

Japan: Shares of JGB Holdings at end-2010

(In percent)

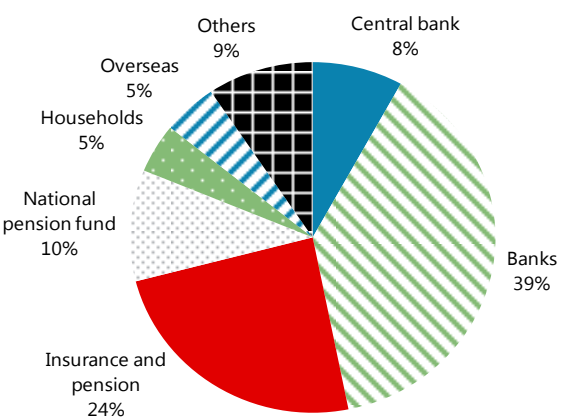

Source: Bank of Japan Flow of Funds statistics
Since the earthquake in March 2011, 10-year JGB yields have stayed stable between 1.0-1.2 percent...

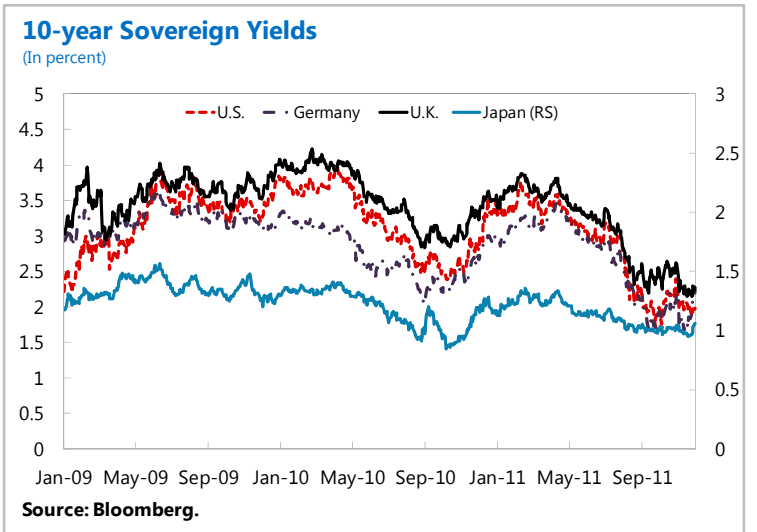

Corporate and households sectors have been recording large financial surpluses, which have been invested mainly in JGBs through banks...

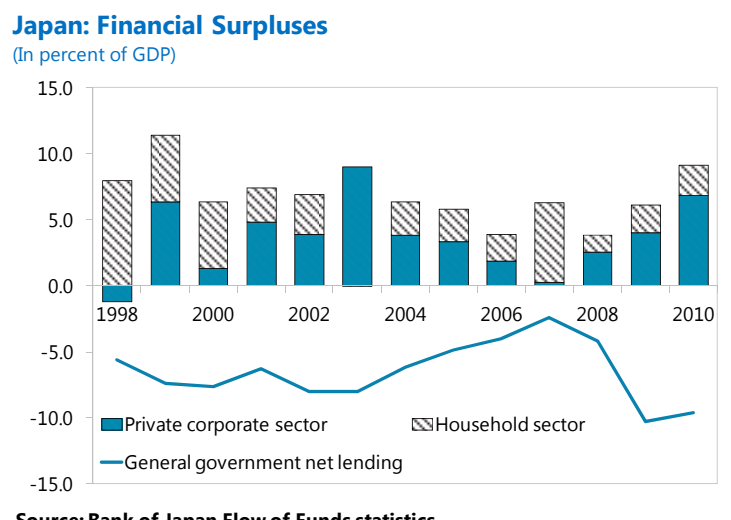

Bank of Japan Flow of Funds statistics

... with a very low reliance on foreign financing.

\section{G5 Economies:}

Share of Foreign Holdings of Government Bonds (In percent)

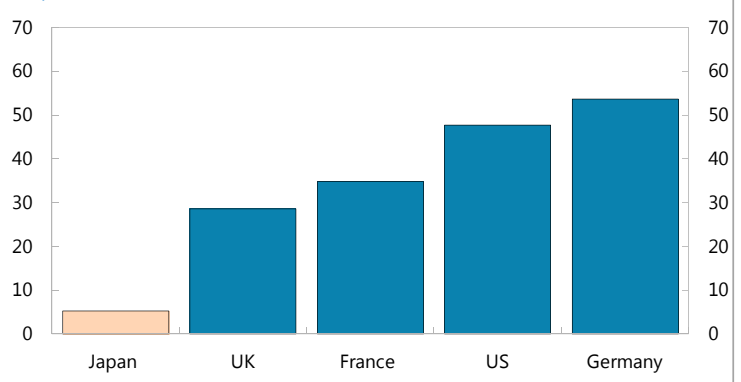

Source: Debt Management Report 2010 (Ministry of Finance). 


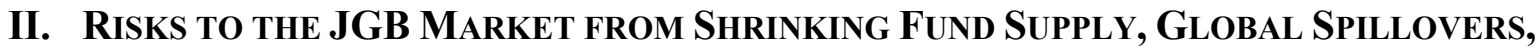 AND MARKeT VolatiLity}

\section{Decline in Fund Supply}

In Japan, large savings by the corporate and household sectors have provided a steady supply of funds to the JGB market. At the macro level, lending and borrowing by the nonfinancial sectors, which consist of the general government, the private corporate sector, the household sector, and private non-profit institutions, are mostly intermediated by the financial sector. ${ }^{2}$ At end-2010, financial assets held by the private corporate and household sectors stood at $¥ 2,275$ trillion ( 450 percent of GDP), exceeding liabilities by $¥ 840$ trillion (about 170 percent of GDP) (Figure 2). ${ }^{3}$ This large domestic surplus has contributed to financing nearly 95 percent of the stock of JGBs domestically.

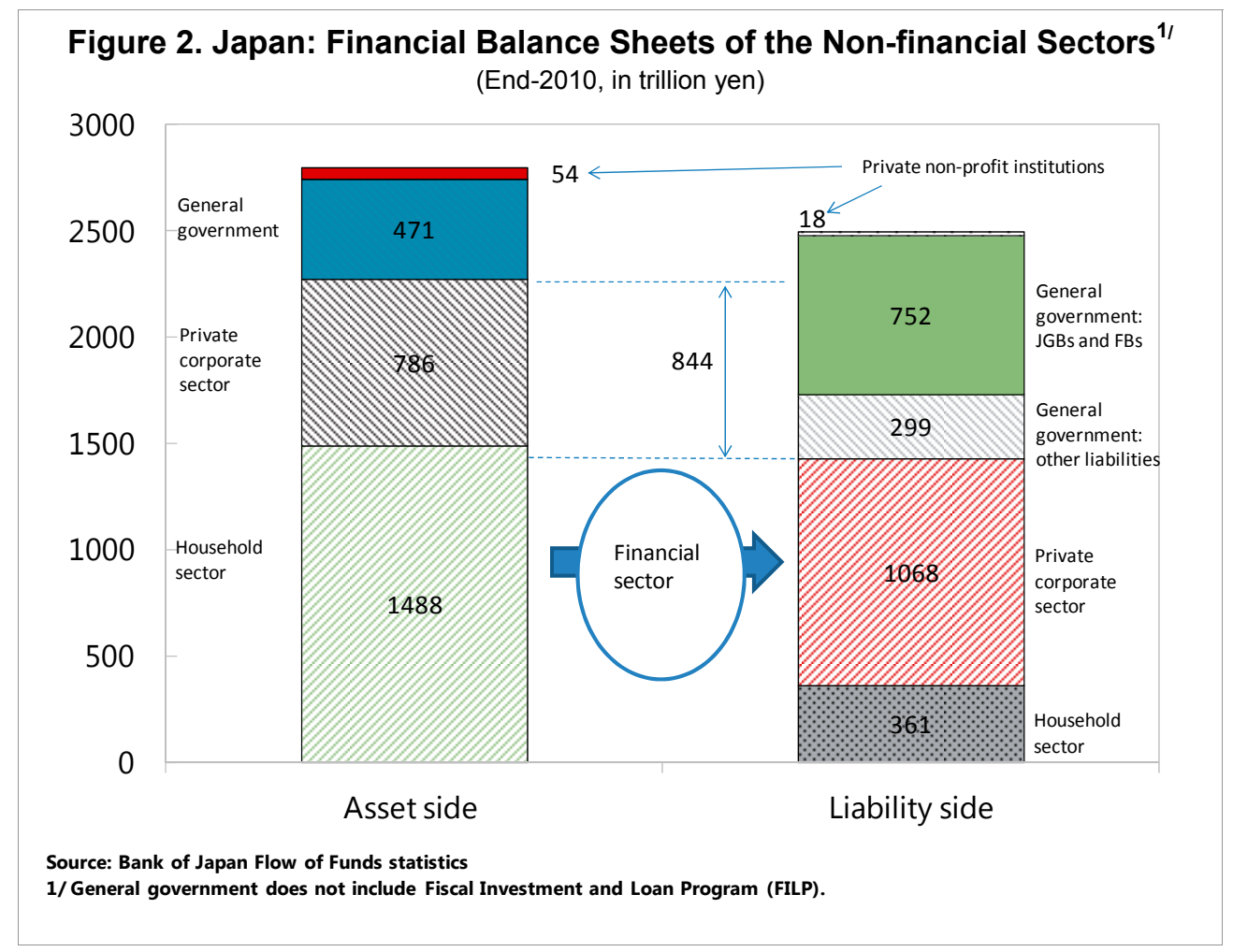

Over the past decade, a gradual increase in deposits and a trend decline in corporate loans have provided additional space for investments in JGBs. Since 2000, household deposits have increased by $¥ 40$ trillion or 8 percent of GDP (Figure 3), supported by declining but still positive household saving rates. During the same period, the stock of corporate loans has declined by about $¥ 100$ trillion ( 20 percent of GDP). These two factors have led to a decline in the loan-deposit ratio from 95 to 70 percent (bottom right chart of

\footnotetext{
${ }^{2}$ Indeed, financial assets and liabilities are almost balanced in the financial sector (excluding the Bank of Japan) with financial assets exceeding liabilities by only 3 percent of GDP at end-2010.

${ }^{3}$ These numbers are calculated on an unconsolidated basis. For example, JGBs held directly by households are not subtracted from the assets or liabilities.
} 
Figure 3) and created significant space for financial institutions to increase their JGB holdings. In addition, the Bank of Japan has also stepped up purchases of JGBs (currently at $¥ 21.6$ trillion yen per year on a gross basis) since the beginning of the global financial crisis and acquired government securities through the new asset purchase program, which has contributed to stable yields. ${ }^{4}$

Over the medium term, however, the market's capacity to absorb new debt is likely to diminish as the population ages. On a stock basis, the household sector has been financing more than half of JGBs either directly or indirectly through banks and other financial intermediaries, but since the 1990s, population aging has reduced the financial surpluses of the household sector. ${ }^{5}$ Going forward, population aging is likely to reduce household surpluses further, and without a

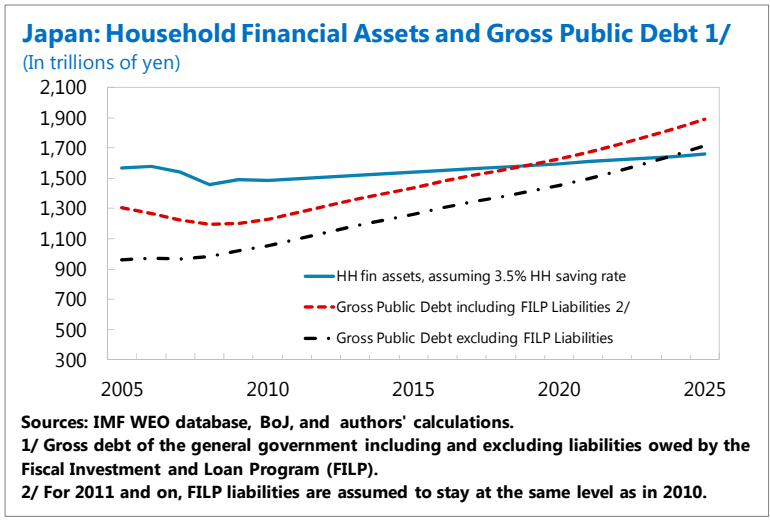
significant policy adjustment, the stock of gross public debt could exceed household financial assets (currently at 300 percent of GDP) in around 10 years, suggesting that Japan may need turn to other sectors, including overseas, to finance its deficit.

\section{In the near term, fund supply to the JGB market from the corporate sector could also} decline. Corporate financial surpluses, which amounted to 7 percent of GDP in 2010, are an important source of JGB funds through the banks. After the global financial crisis, these surpluses rose sharply as corporates postponed investment and capped wages. Looking ahead, these surpluses could decline as corporates undertake investment for reconstruction or expansion overseas.

\section{At the same time, demand for JGBs from pension funds could also weaken if pension} payouts accelerate. Amid population aging, one of the largest institutional investors, the National Pension Fund, has already begun reducing assets to make payouts to retirees.

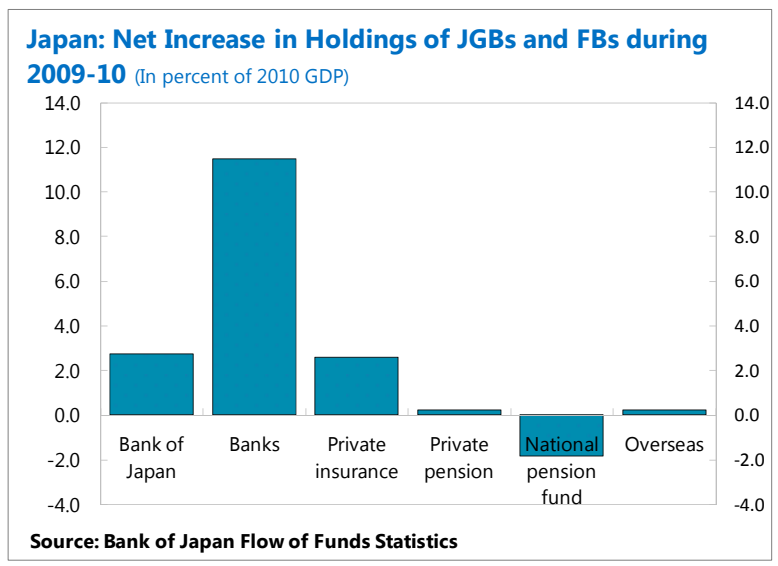

\footnotetext{
${ }^{4}$ See Bank of Japan (2011), Berkmen (2011), Lam (2011), and Ueda (2011).

${ }^{5}$ See Tokuoka (2010).
} 


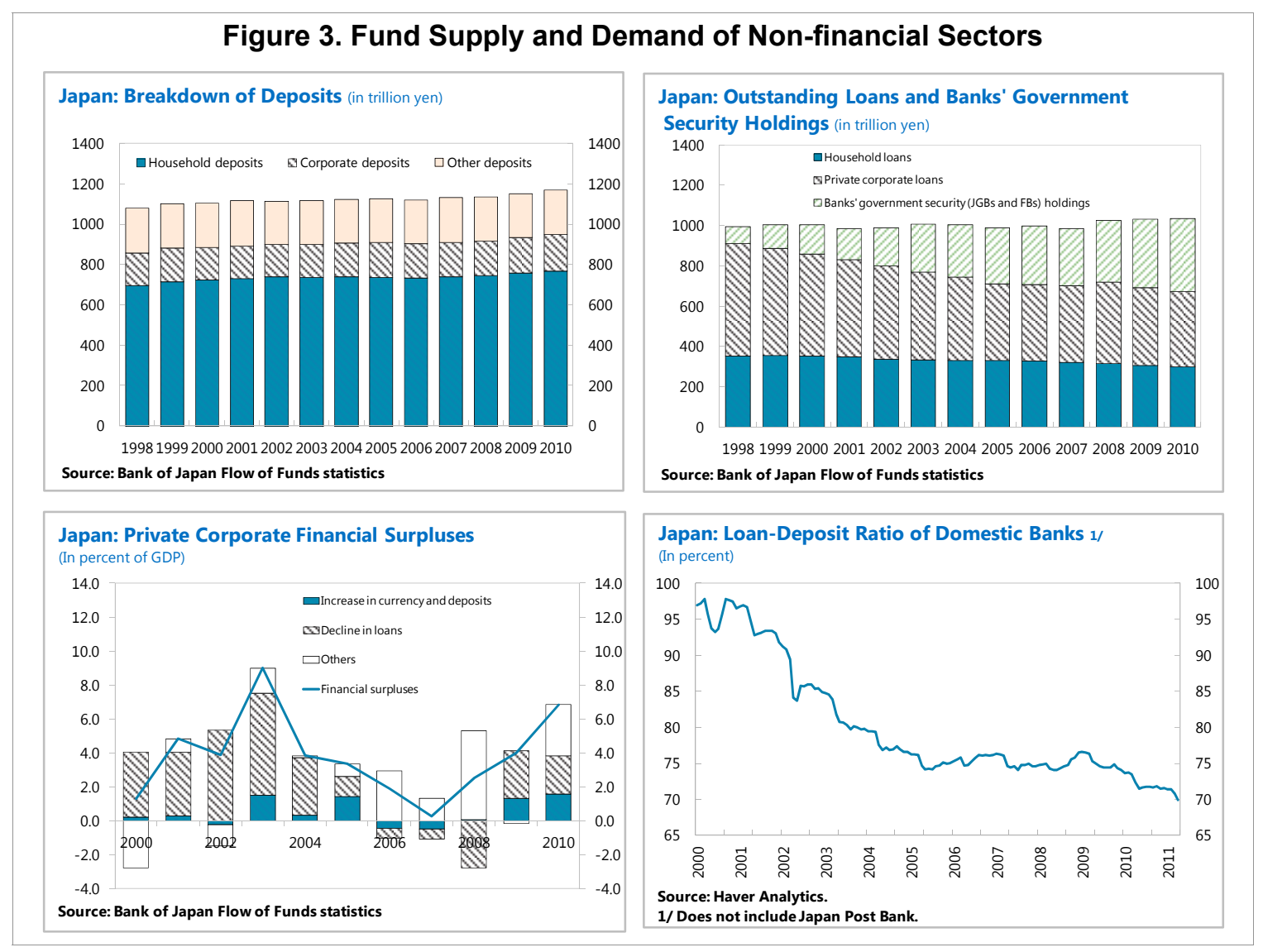

Estimating a basic demand function for government securities can help assess the impact of a decline in corporate and household financial surpluses on banks' JGB holdings. Here we estimate the following equation:

$$
\text { govtsec }=\beta_{1} \text { loans }+\beta_{2} \text { deposits }+\beta_{3} \text { control variables, }
$$

where govtsec is banks' holdings of central government securities (JGBs and FBs), ${ }^{6}$ loans is the stock of bank loans, and deposits is the sum of corporate and household sector deposits (all in percent of GDP). Control variables include real GDP growth, spreads between longterm prime lending rates and 10 -year JGB yields, and CPI inflation. ${ }^{7}$ This equation estimates how much govtsec would increase when loans decline and deposits rise. While there is an endogeneity issue between govtsec and loans,${ }^{8}$ Granger causality tests suggest that a decline in loans leads to an increase in govtsec, and not in the opposite direction. ${ }^{9}$ Financial surpluses of the corporate and household sectors channeled through the banking sector are observed when loans decrease or deposits increase, or both. Thus, if financial surpluses of these

\footnotetext{
${ }^{6}$ Excluding Japan Post Bank due to data constraints.

${ }^{7}$ These variables are included to control for business cycles and risk appetite. Including other variables (e.g., equity returns) to control for risk appetite does not change the results much.

${ }^{8}$ For example, banks may reduce loans to purchase government bonds.

${ }^{9}$ Using first differences, the hypothesis that loans do not Granger-cause govtsec is rejected at the 1 percent level, while the hypothesis of no Granger-causality in the reverse direction is not rejected at the 10 percent level.
} 
sectors have a positive impact on banks' holdings of central government securities, the coefficients in the regressions should read as $\beta_{1}<0$ and $\beta_{2}>0$. We run regressions in level form assuming cointegration (where estimates are robust to endogeneity). ${ }^{10}$

\section{The results suggest that a decline in financial surpluses of the corporate and household} sectors could significantly reduce banks' purchases of central government securities.

The estimates indicate that a 1 percent of GDP increase in loans would reduce banks' holdings of central government securities by $0.3-0.6$ percent of GDP, while a similar decline in deposits would cut banks' holdings of these securities by $0.5-0.9$ percent of GDP (Table 1). The last column of the table shows the results with the main independent variables interacted with the post-Lehman dummy. These additional terms are statistically insignificant, suggesting the effects of loans and deposits have not changed substantially before and after

Table 1. Impact of Loans and Deposits on Banks' Holdings of Government Securities ${ }^{1,21}$

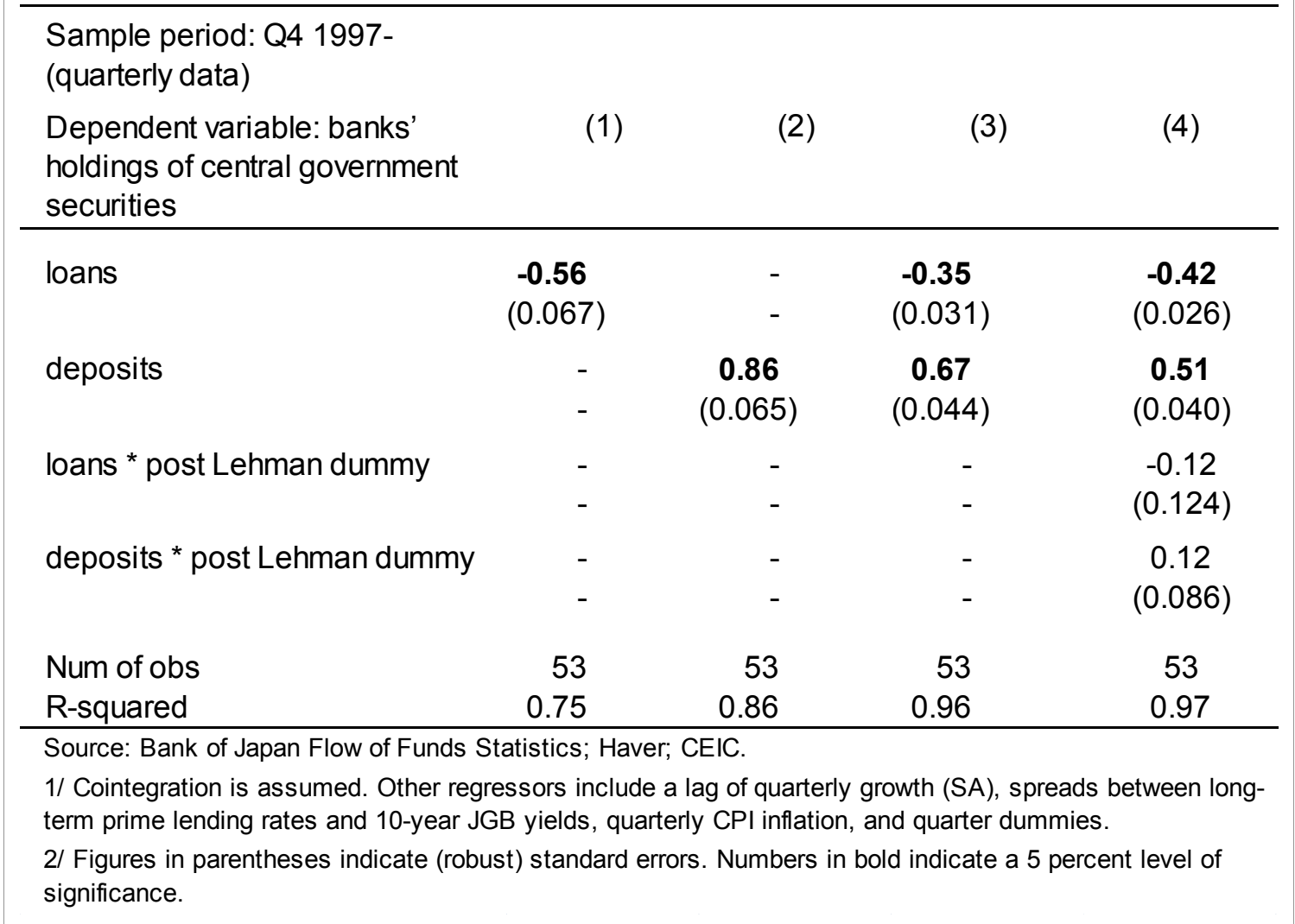

\footnotetext{
${ }^{10}$ Unit root is not rejected for govtsec, deposits, or loans, but is rejected for the residual in the estimated equation. This suggests that the three variables (govtsec, deposits, and loans) are cointegrated and that the results are not subject to endogeneity bias.
} 
the peak of the global financial crisis. The estimates in the table in turn imply that if (net) repayment of loans and accumulation of deposits of the corporate sector cease - as happened at the peak of the previous business cycle in 2007and corporate financial surpluses decline by 4 percent of GDP, banks' net government security purchases could fall by 1-3 percent of GDP. This would be a sizeable reduction, compared to the annual net government debt issuances in recent years (10 percent of GDP).

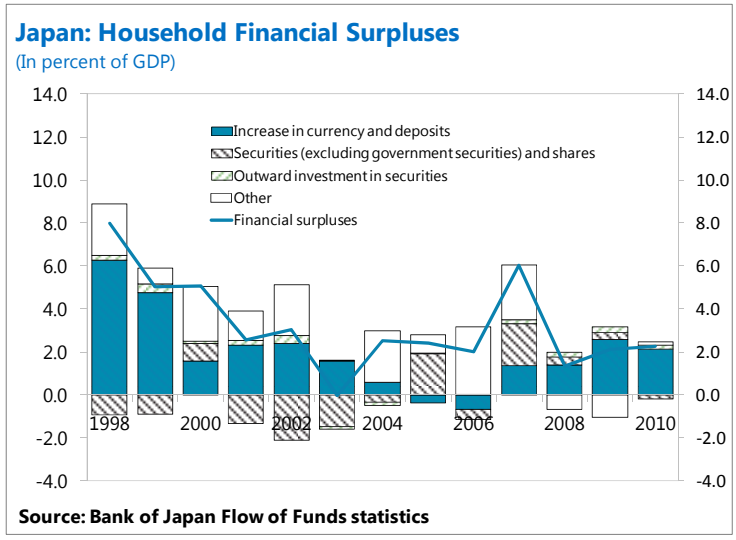

A decline in corporate financial surpluses does not necessarily lead to higher JGB yields. This is because a decline in corporate financial surpluses is typically accompanied by a recovery in domestic demand and higher tax revenue, which would reduce the need for debt financing. This also occurred during Japan's previous expansion between 2003 and 2007 (middle right chart of Figure 1), when corporate financial surpluses fell from nearly 10 percent of GDP in 2003 to zero in 2007 as business investment boomed. However, overall fiscal deficits also declined by $5 \frac{1}{2}$ percent of GDP thanks to a cyclical tax recovery and spending cuts, while the household sector maintained its financial surpluses. Consequently, the JGB market experienced little funding pressure, with 10-year JGB yields staying below 2 percent even at the peak of the recovery.

\section{There are three risks to such a "good" scenario in the current business cycle.}

- $\quad$ The corporate sector might accelerate its overseas expansion. In recent years, corporate outward direct investment (equity acquisition) has remained around 1 percent of GDP, but corporates are increasingly looking overseas given the strong yen and shrinking domestic market. ${ }^{11} \mathrm{~A}$ further shift in investment overseas would reduce corporate surpluses held in bank deposits to finance JGBs. $^{12}$

\section{- Projected declines in fiscal deficits might}

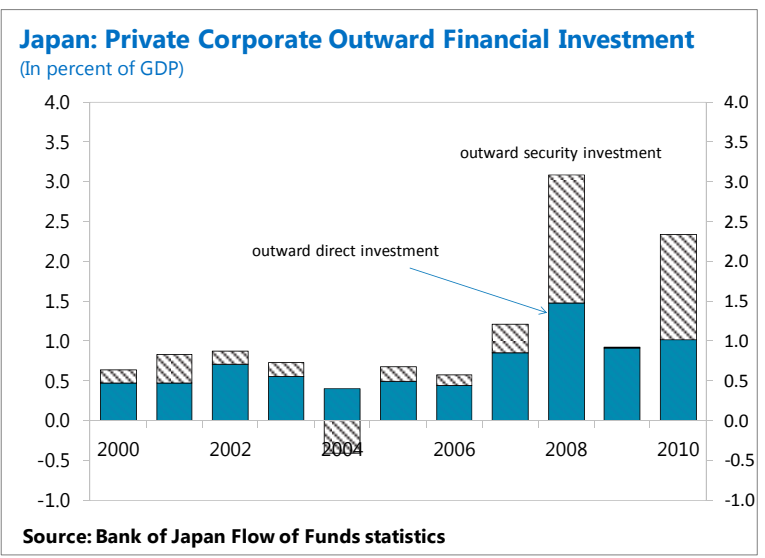

not be enough to offset the impact of lower corporate financial surpluses. In particular, even under the authorities' plan, overall fiscal deficits would narrow only by 3 percent of

\footnotetext{
${ }^{11}$ According to a recent survey by Teikoku Data Bank (July 2011), 25 percent of manufacturing companies believe that oversea investment will accelerate. Overseas mergers and acquisitions activities by Japanese corporations have already increased significantly to a record of 3 trillion yen ( 0.6 percent of GDP) in the first six months of 2011.

${ }^{12}$ Over time, oversea investments will contribute to corporate surpluses through repatriation of profits, but in the short term, an increase in oversea investments is likely to result in net cash outflows.
} 
GDP during the next 5-6 years,$^{13}$ compared to $5 \frac{1}{2}$ percent of GDP during the previous expansion period of 2003-07. This reflects more limited room for expenditure cuts than in the past.

- A shift in households' asset portfolio could also reduce demand for JGBs. For example, the estimates in Table 1 imply that if households' net purchases of securities (excluding government securities) and shares bounce back to 2 percent of GDP (2007 level) as risk appetite recovers, that could reduce banks' purchases of government securities by $1 \frac{1}{2}-2$ percent of GDP through slower accumulation of deposits.

\section{Based on historical trends, a decline in corporate and household financial surpluses} would likely have a modest impact on yields, but a more substantial response cannot be ruled out. Japan's historical data suggest that the immediate impact on yields from a decline in corporate financial surpluses even to zero would be at most about 10 basis points. ${ }^{14}$ However, the response of yields to a funding shock could be nonlinear and more significant once public debt exceeds a certain threshold..$^{15}$

\section{Market Volatility}

\section{Banks' large and increasing holdings of JGBs are a key source of vulnerability.} Since mid-2008, banks have increased JGB holdings by $¥ 40$ trillion or 8 percent of GDP amid a flight to safety and increasing private sector surpluses as discussed above. During this period, they have earned higher returns from JGBs than from alternative investments (for example, nominal returns from U.S. Treasuries in yen terms have been negative due to the yen's appreciation and narrowing interest differential). However, with banks'

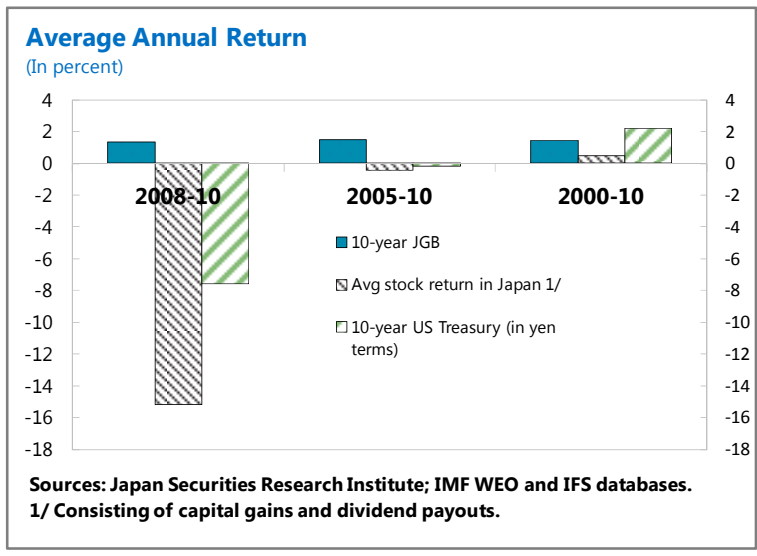

(excluding Japan Post Bank) outstanding JGB holdings rising to $¥ 150$ trillion (more than 15 percent of their total assets), they now face higher interest rate risk.

\section{A rise in market volatility that prompts banks to unwind their JGB holdings could be triggered in several ways.}

- Shortening of maturities. Major banks have been shortening the maturities of their JGB holdings to an average of about 2 years in FY2010 (from 3.2 years in 2002-03) in

\footnotetext{
${ }^{13}$ For example, the Cabinet Office projected in August 2011 that assuming an increase in the consumption tax rate to 10 percent by FY2015, the general government overall fiscal deficit (excluding the social security fund) would narrow by only 3 percent of GDP between FY2010-15.

${ }^{14}$ Estimated using regression results in Tokuoka (2010), which report that a decline in corporate or household financial net worth of 1 percent of GDP would raise 10-year JGB yields by 1-2 basis points.

${ }^{15}$ There is some empirical evidence consistent with the view that the impact of a rise in debt on yields is nonlinear and becomes significant once the debt exceeds a certain threshold (e.g., Faini, 2006; Ardagna, Caselli, and Lane, 2004).
} 
response to higher interest rate risk. Higher interest rate volatility could further push banks - particularly the regional banks, which hold longer maturity JGBs (about $3 \frac{1}{2}$ years) - to further shorten the maturity.

- Banks' risk management practice. Higher interest rate volatility could induce a JGB selloff if banks' risk exposures exceed the calculated thresholds of their risk management model. A notable example was the so-called 'VaR shock' in June 2003, when 10-year JGB yields more than tripled over three months, surging from a historically low of 0.5 percent to 1.6 percent (Figure 4). ${ }^{16}$ Although banks have now strengthened risk management practices by including qualitative assessment in addition to the quantitative risk measures in VaR models, banks' JGB holdings are significantly larger, compared to 10 years ago.

- Rating downgrade. Although recent sovereign downgrades have had limited impact on JGB yields, a further rating downgrade or a series of weak JGB auctions that push up yields volatility could induce banks to reduce the duration of JGB holdings or to sell JGBs to limit losses. This could in turn lead foreign investors to unwind their positions in the futures and swaps markets. ${ }^{17}$

- Rollover risk. The rollover risks of JGBs have risen along with the government's annual financing requirement, which now amounts to about 55 percent of GDP (including financing bills) - the highest among advanced economies. The large financing needs reflect not only the high debt stock but also their relatively short average maturity, which is still around 5 $1 \frac{1}{2}-6$ years (including financing bills) despite the recent lengthening. ${ }^{18}$ Given the

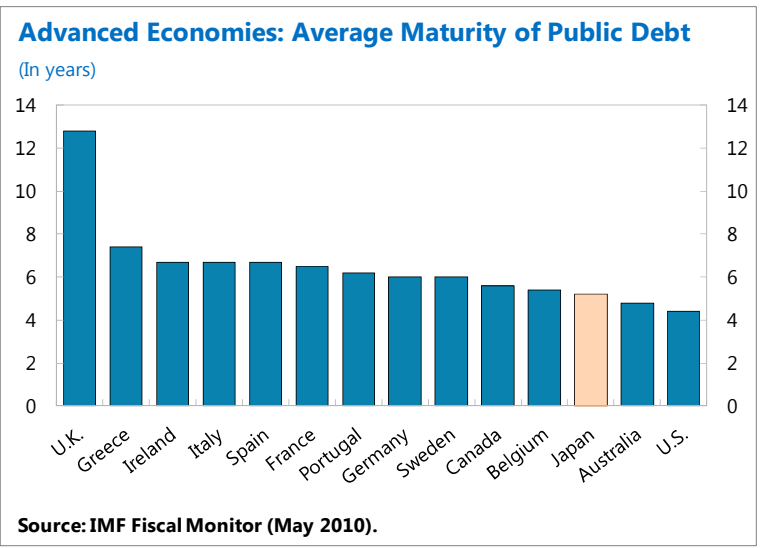

${ }^{16}$ This episode was termed the "VaR shock" because the rise in volatility increased risk measures in banks" internal value-at-risk (VaR) models and led to one-sided selling by banks as they attempted to shed risk (Bank of Japan, 2010).

${ }^{17}$ A large portion of JGB holdings are held in banks' balance sheet as 'available-for-sale' or 'held-to-maturity' accounts outside the trading book. Banks would need to provide impairments for the valuation losses depending on the magnitude of the losses (in practice if market value falls below 70 percent of the book value). In case banks apply internal risk-based method and use zero risk weight on their JGB holdings, market investors could price in the perceived increase in risk on bank valuation. A sustained rise in sovereign yields could pose interest rate risks to banks' balance sheets. Unexpected illiquidity in the JGB market and the uncertain prospect of fiscal consolidation could also dampen their prices.

${ }^{18}$ According to the authors' estimates, the average maturity rose from 4.7 years at end-FY2005 (March 2006) to 5.8 years at end-FY2010. 
large amount of bonds that need to be rolled over, any increase in uncertainty over the supply and demand of JGBs could disrupt the smooth absorption of new issuances and push up JGB yields. ${ }^{19}$

\section{Global Spillovers}

\section{Global financial distress could have negative spillover effects on the JGB market through the banking system.} Japan's sovereign yields are sensitive to global risks, such as the investors' risk appetite. For example, the correlation between 10 -year yields (returns) on JGBs and U.S.

Treasuries ranges from 0.37 to 0.58 (Table 2). In response to capital losses on their foreign bond portfolios, Japanese banks could reduce the maturity to minimize losses. For example, in late 2010, the sudden rise in JGB yields holdings and shortened maturities in response to losses on their U.S. Treasuries. So far the European turmoil has had limited impact on the JGB market. JGB yields - along with the U.S. and Germany sovereigns - declined during the recent European sovereign distress due to 'safehaven' flows. However, if sovereign distress spreads more globally, that could also raise the risk premium on JGBs.

Table 2. Correlation of Japanese Sovereign Yields

\begin{tabular}{lccc}
\hline Correlation with 10-year JGB yields 1/ & $\begin{array}{c}\text { 10-year US } \\
\text { Treasury yields }\end{array}$ & $\begin{array}{c}\text { 10-year German } \\
\text { bond yields }\end{array}$ & $\begin{array}{c}\text { Average yields of } \\
\text { adv. countries 2/ }\end{array}$ \\
\hline Entire sample: (Jan 2000 - May 2011) & 0.58 & 0.37 & 0.49 \\
Before Jan 2008 & 0.61 & 0.19 & 0.44 \\
After Lehman crisis & 0.62 & 0.87 & 0.75 \\
\hline
\end{tabular}

Source: Bloomberg.

1/ Correlation coefficients refer to the correlation of 10-year JGB yields in levels and they are all statistically significant at the 5 percent level.

2/ Average yields refer to the average of 10 -year yields on U.S. Treasury, German sovereign bonds, and U.K. Treasury bonds.

\section{Another channel for global spillover could be through the derivatives markets where} foreign participation is high. Despite low foreign ownership of JGBs (5 percent of the total outstanding), foreign investors are active in the JGB futures market, holding about one-third of outstanding contracts. ${ }^{20}$ Compared to domestic players, foreign investors also appear to be more sensitive to Japanese sovereign risk, as indicated by the rise in spreads on JGB CDS

\footnotetext{
${ }^{19}$ For example, so called "FILP shock" took place in 1998 when yields spiked due to confusion over the purchases of JGBs by the Fiscal Investment and Loan Program (FILP) Special Account.

${ }^{20}$ Statistical analysis, however, does not point to a particular direction of causality.
} 
contracts - traded mostly among foreign investors. ${ }^{21}$ Any distress sell-offs in the futures market could affect the JGB cash market given the close arbitrage links. Overseas financial distress could lead to a rise in global yields, which in turn could amplify pressures on JGB yields through the derivatives markets (Figure 4).

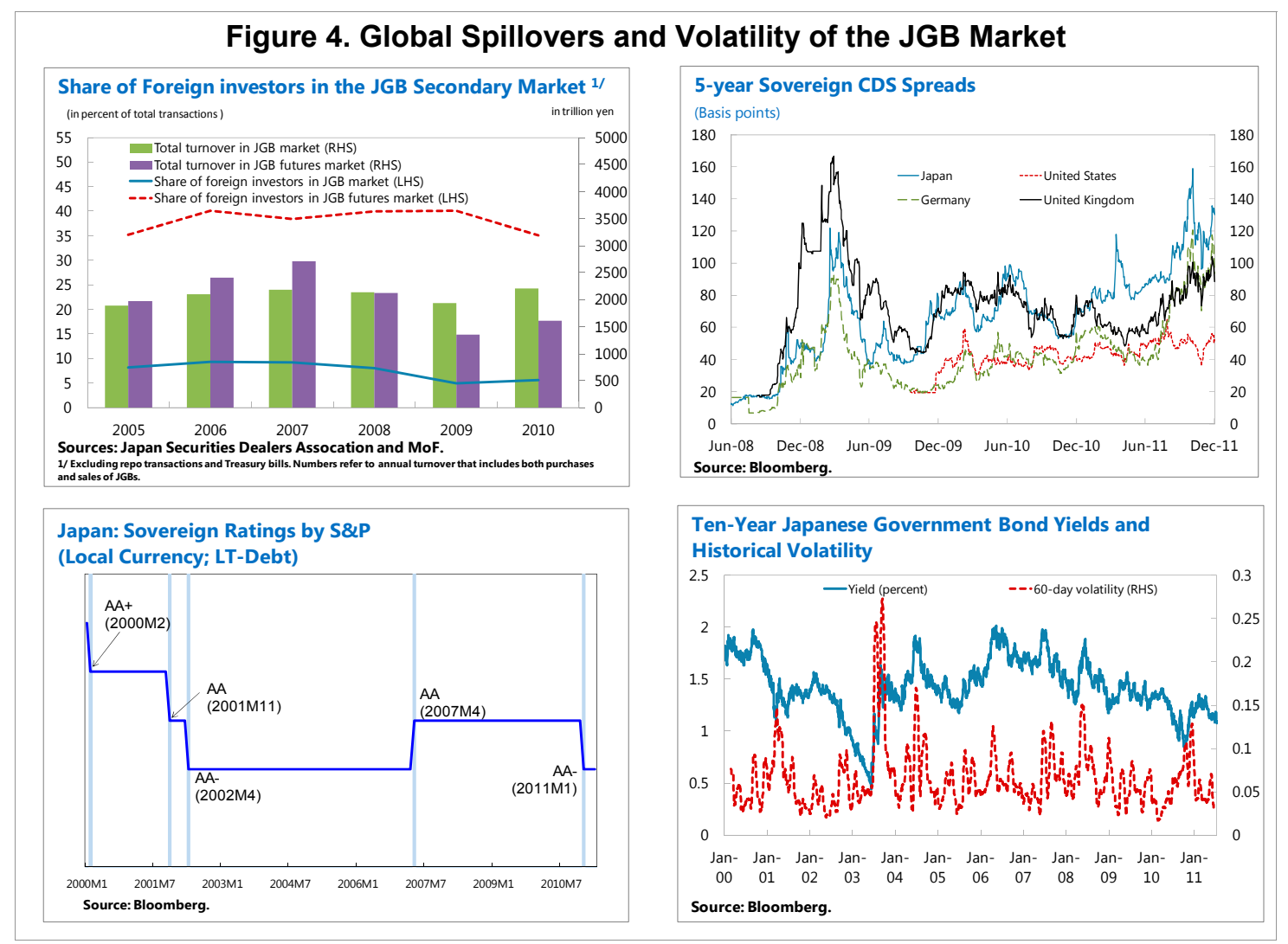

Estimating the sensitivity of the JGB yields to global risk factors can help assess the potential impact from global spillover. We estimate the global spillover channel by using a time-series regression and taking into account global factors and investors' risk appetite. ${ }^{22}$ Granger-causality tests show that movements in global yields generally precede those of JGBs, while the reverse causality from JGB yields to global yields does not appear to be statistically significant. ${ }^{23}$ The results indicate that U.S. Treasury and German sovereign yields

\footnotetext{
${ }^{21}$ Japan's CDS market is not very liquid and consists mainly of foreign hedge funds. Foreign investors looking to short JGBs typically acquire short positions on JGB futures, or buy out-of-the-money put options on interest rate swaps.

${ }^{22}$ The analysis uses daily data from 2005 with an ARIMA specification that accounts for the auto-regressive and heteroscedastic features of short-term yield movement. Lagged variables are used as explanatory variables. An ARIMA model applied as a statistical test on sovereign yields suggests that the time series are non-stationary. The regression includes U.S. Treasury and German Bund yields, and the implied volatility of JGB yields as a proxy for investor's risk appetite. Other risk factors include exchange rate volatility and term premia. These risk factors in essence capture both domestic and external risks.

${ }^{23}$ The hypothesis that 10 -year U.S. Treasury yields and 10 -year German sovereign yields do not Granger-cause 10-year JGB yields are rejected with F-statistics equal to 51.7 and 35.4 (both p-values close to zero), indicating the statistical significance at the 5 percent level. However, the reverse causality from 10-year JGB yields to 10-year
} 
are significant at the 5 percent level (Table 3). These estimates imply, for example, that a one percentage point increase in U.S. Treasury yields (or a change in global risk factors that raise U.S. Treasury yields by one percentage point) could increase JGB yields by nearly 15 basis points. Other things being held constant, JGB yields were more closely driven by U.S. Treasury yields after the global financial crisis. In addition, uncertainty in the financial markets, such as measured by the implied volatility of JGBs, also have a strong impact on JGB yields. This would imply that a rise in global uncertainty, which is reflected in a higher volatility of JGBs, could raise the risk premium in JGBs. Based on the estimates, a rise of implied volatility, similar to what took place after the Lehman crisis, could push up JGB yields by more than 40 basis points, holding other variables constant. ${ }^{24}$

\begin{tabular}{|c|c|c|c|}
\hline $\begin{array}{l}\text { Sample period: } \\
\text { Jan } 2006 \text { - May } 2011 \\
\text { Dependent variable: } 10 \text {-year JGB } \\
\text { yields }\end{array}$ & (1) & (2) & (3) \\
\hline 10-year U.S. Treasury yields & $\begin{array}{r}\mathbf{0 . 1 6} \\
(0.01)\end{array}$ & $\begin{array}{r}0.13 \\
(0.01)\end{array}$ & $\begin{array}{r}\mathbf{0 . 1 2} \\
(0.01)\end{array}$ \\
\hline $\begin{array}{l}\text { 10-year German sovereign bond } \\
\text { yields }\end{array}$ & - & $\begin{array}{r}0.10 \\
(0.02)\end{array}$ & $\begin{array}{r}\mathbf{0 . 1 0} \\
(0.02)\end{array}$ \\
\hline Implied volatility of JGBs $3 /$ & $\begin{array}{r}\mathbf{0 . 0 5} \\
(0.00)\end{array}$ & $\begin{array}{r}\mathbf{0 . 0 5} \\
(0.01)\end{array}$ & $\begin{array}{r}\mathbf{0 . 0 5} \\
(0.01)\end{array}$ \\
\hline Equity returns (Nikkei) & $\begin{array}{l}-0.07 \\
(0.03)\end{array}$ & $\begin{array}{l}-0.09 \\
(0.03)\end{array}$ & $\begin{array}{r}-0.09 \\
(0.03)\end{array}$ \\
\hline Term premium $3 /$ & - & $\begin{array}{r}0.14 \\
(0.05)\end{array}$ & $\begin{array}{r}\mathbf{0 . 1 4} \\
(0.05)\end{array}$ \\
\hline Dummy*U.S Treasury yields 4/ & - & - & $\begin{array}{r}0.01 \\
(0.00)\end{array}$ \\
\hline \multicolumn{4}{|c|}{$\begin{array}{l}\text { Source: Bloomberg } \\
\text { 1/ All variables included in the regression refer to the first lags. } \\
\text { 2/ Figures in parentheses indicate the standard errors. Numbers in bold indicate } \\
\text { a } 5 \text { percent level of significance. } \\
3 \text { / Implied volatility refers to } 30 \text {-day implied volatility of } 10 \text {-year JGBs as calculated } \\
\text { based on underlying options. Term premium refers to the slope between 2-year } \\
\text { and } 5 \text {-year JGBs. } \\
\text { 4/ The dummy variable spans from September } 2008 \text { to April } 2009 \text { to include } \\
\text { the peak of the global financial crisis. }\end{array}$} \\
\hline
\end{tabular}

U.S. Treasury yields or 10-year German yields is not statistically significant, with p-values close to 0.3 and 0.2 , respectively.

${ }^{24}$ Alper and Forni (2011) suggest a notable spillover of government bond yields from advanced countries by as much as 30 basis points on average across the advanced and emerging economies, after controlling for domestic and global fundamentals. 
Further regressions also suggest that market risk to the JGB market is subject to global factors. Sovereign risks as measured by the CDS spreads are in general positively correlated with the fiscal positions. Higher public debt ratio as a percent of GDP is usually associated with higher sovereign CDS spreads. In the case of Japan, the relations between the CDS spreads and fiscal variables are less clear than other advanced countries. Nevertheless, its sovereign CDS spreads are highly correlated to developments in global financial markets, particularly in the United States and Europe. A rise in CDS spreads in the United States and Europe, and lower global equity returns are found to be correlated with an increase in CDS spreads in Japan at the 5 percent significance level. Specifically, a one-percentage rise in the composite CDS spreads in advanced countries could raise Japan's CDS spreads by 30 basis points.

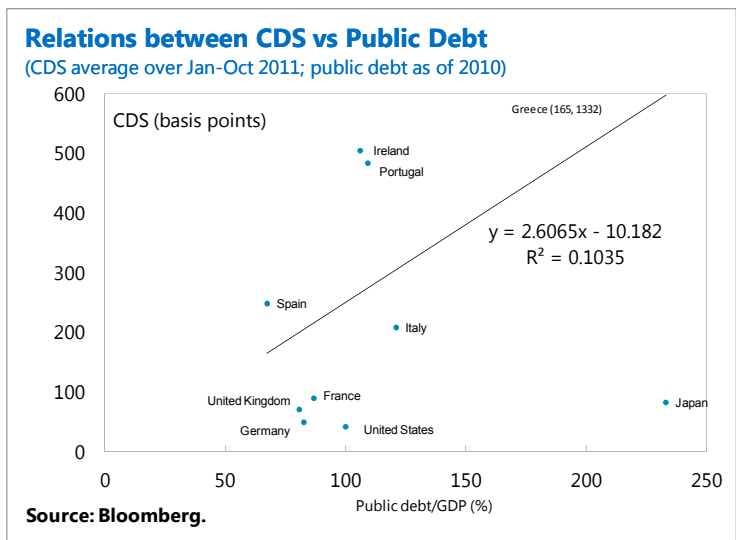

Relations between CDS vs Public Debt

Table 4. Financial Indicators Influencing Sovereign Risk ${ }^{1 / 2 /}$

\begin{tabular}{|c|c|c|c|}
\hline $\begin{array}{l}\text { Sample Period: } \\
\text { May } 2009 \text { - June } 2011 \\
\text { Dependent variable: } 5 \text {-year } \\
\text { Sovereign CDS for Japan }\end{array}$ & (1) & (2) & (3) \\
\hline $\begin{array}{l}5 \text {-year sovereign CDS spreads } \\
\text { (advanced countries) } 3 /\end{array}$ & $\begin{array}{r}\mathbf{0 . 4 9} \\
(0.07)\end{array}$ & $\begin{array}{r}0.30 \\
(0.09)\end{array}$ & $\begin{array}{r}0.30 \\
(0.08)\end{array}$ \\
\hline $\begin{array}{l}\text { Sovereign yields differential } \\
\text { between U.S. and Japan } 3 /\end{array}$ & $\begin{array}{r}-5.39 \\
(1.39)\end{array}$ & $\begin{array}{r}-3.47 \\
(1.61)\end{array}$ & $\begin{array}{r}-3.57 \\
(1.63)\end{array}$ \\
\hline Global equity returns & - & $\begin{array}{r}-0.29 \\
(0.08)\end{array}$ & $\begin{array}{r}-0.28 \\
(0.08)\end{array}$ \\
\hline Implied volatility of Nikkei 3/ & - & $\begin{array}{r}0.14 \\
(0.03)\end{array}$ & $\begin{array}{r}0.13 \\
(0.03)\end{array}$ \\
\hline LIBOR-OIS spreads & - & - & $\begin{array}{r}0.24 \\
(0.12)\end{array}$ \\
\hline \multicolumn{4}{|c|}{$\begin{array}{l}\text { Source: Bloomberg } \\
1 / \text { All variables included in the regression refer to the first lags. }\end{array}$} \\
\hline \multicolumn{4}{|c|}{$\begin{array}{l}\text { 2/ Figures in parentheses indicate the standard errors. Numbers in bold indicate a } 5 \\
\text { percent level of significance. }\end{array}$} \\
\hline \multicolumn{4}{|c|}{$\begin{array}{l}\text { 3/ Sovereign spreads for advanced countries refer to the composite sovereign CDS } \\
\text { spreads including the U.S., and the } 10 \text { largest European countries. The sovereign yields } \\
\text { differential is the } 5 \text {-year U.S. Treasury net of } 5 \text {-year JGB yields (presumably, this captures } \\
\text { domestic factors that may drive risk premium). Implied volatility is calculated on } \\
\text { underlying option prices. }\end{array}$} \\
\hline
\end{tabular}




\section{RISKS FROM A RISE IN JGB YIELDS}

\section{A significant rise in yields would leave the fiscal position extremely vulnerable. If} sovereign yields rise by 100 basis points over the next 5 years, the net debt-to-GDP ratio would remain at high levels over the long term, even after a 10 percentage points of GDP adjustment in the structural fiscal balance to anchor sustainability. ${ }^{25}$ The high debt levels would leave the fiscal position vulnerable to interest rate or funding shocks and risk undermining public confidence.

\section{Yield increases could also pose a risk to}

banks. With banks holding a large amount of JGBs (more than 15 percent of total assets, excluding Japan Post Bank), a rise in yields would generate capital losses. For example, a 100 basis point increase in interest rates across all maturities would generate capital losses of around $¥ 500$ billion at the major banks and about $¥ 400$ billion at the regional banks as of FY2010 according to the BoJ. This corresponds to 10 percent of major banks' tier 1 capital and more than 30 percent of regional banks' tier 1 capital, respectively. ${ }^{26}$
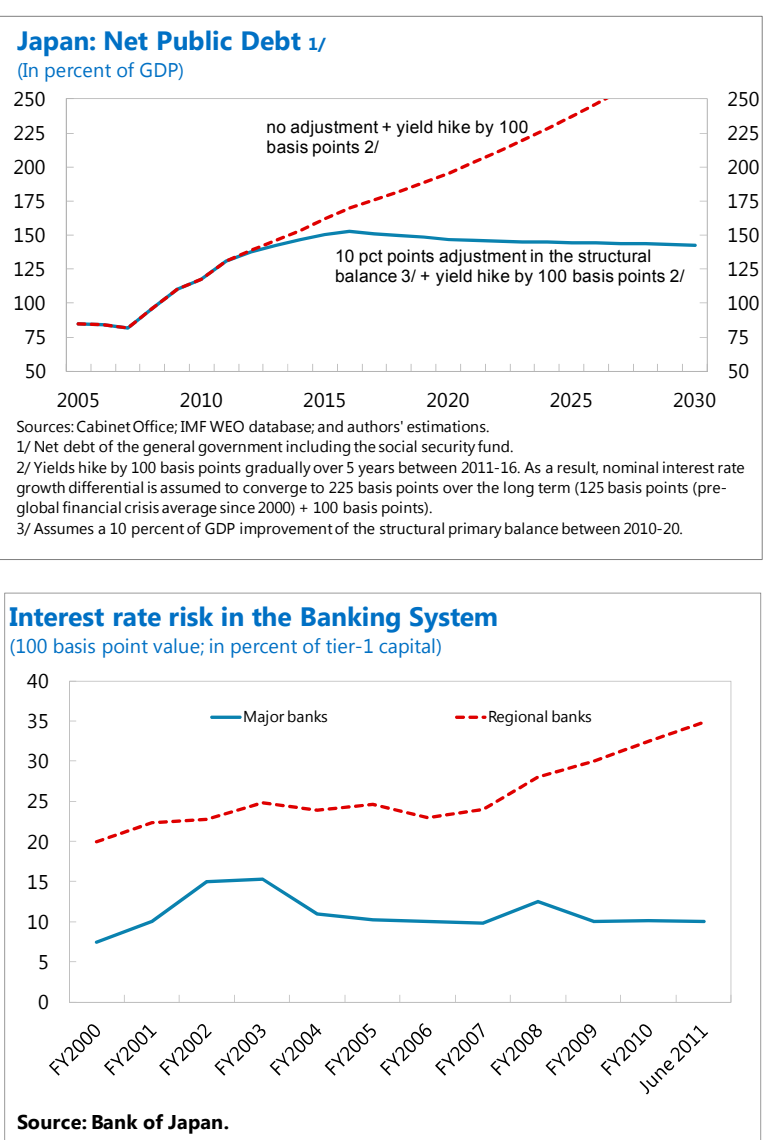

\section{Potential spillovers from a sovereign stress in Japan would hit a large segment of the} Japanese financial sector. Using a probability-based distress model, we estimate the potential impact arising from a hypothetical sovereign distress event in Japan on Japanese financial institutions in general (not just banks) ${ }^{27}$ Compared to periods before the global financial crisis, the impact of a sovereign distress on individual financial institutions has significantly risen, partly driven by higher JGB holdings in the financial system and the higher sensitivity of market investors to the linkages between sovereign risks and distress among financial institutions.

\footnotetext{
${ }^{25}$ See IMF (2011) for a list of possible measures to achieve a 10 percentage points adjustment.

${ }^{26}$ The IMF's Global Financial Stability Report (October 2010) and the Bank of Japan's Financial System Report (September 2010).

${ }^{27}$ The probability-based distress model was developed by Segoviano (2006) and Segoviano and Goodhart (2009) to analyze the interconnectedness and the common dependence on specific shocks. The analysis uses daily data of the equity prices and CDS spreads of large Japanese financial institutions from November 2006 to June 2011. Distress refers to the case when the CDS spreads of sovereign or individual financial institutions exceed the tail 5 percent VaR threshold that is implied by the data.
} 


\section{Conclusions}

Stabilizing and reducing public debt is critical to maintaining confidence in the JGB market as the factors holding down JGB yields could diminish over time. A decline in fund supply, particularly from the corporate sector, higher market volatility, and spillovers from global financial distress could put upward pressure on JGB yields. To limit these risks, fiscal policy should aim to reduce public debt quickly. Given the limited scope for expenditure cuts, fiscal adjustment should take a balanced approach that involves both raising revenue and curbing expenditure growth. Lengthening maturities of JGBs would also lock in low interest rates, while reducing roll-over risks. 


\section{REFERENCES}

Alper, Emre, and Lorenzo Forni, 2011, "Public Debt in Advanced Economies and its Spillover Effects on Long-term Yields," IMF Working Paper No. 11/210 (Washington: International Monetary Fund).

Ardagna, Silvia, Francesco Caselli, and Timothy Lane, 2004, "Fiscal Discipline and the Cost of Public Debt Service: Some Estimates from OECD Countries," NBER Working Paper Series, No. 10788 (Cambridge, Massachusetts, National Bureau of Economic Research).

Bank of Japan, 2010, Financial System Report, September.

Berkmen, S. Pelin, 2011, “Bank of Japan's Quantitative and Comprehensive Easing: Are They Now More Effective?," forthcoming IMF Working Paper.

Bolton, Patrick and Olivier Jeanne, 2011, "Sovereign Default Risk and Bank Fragility in Financially Integrated Economies,” NBER Working Paper No. 16899, March 2011, (Cambridge, Massachusetts, National Bureau of Economic Research).

Faini, Riccardo, 2006, "Fiscal Policy and Interest Rates in Europe," Economic Policy, Vol. 21, No. 47, pp. 443-489.

International Monetary Fund, 2011, Japan: Staff Report for the 2011 Article IV Consultation, IMF Country Report No.11/181 (Washington: International Monetary Fund).

International Monetary Fund, 2010, Global Financial Stability Report, October.

Kallestrup, Rene, David Lando, and Agatha Mugoci, 2011, "Financial Sector Linkages and the Dynamics of Bank and Sovereign Credit Spreads," mimeo, July. http://forskerskolen.rente.nhh.no/portals/0/Files/lando.pdf

Lam, Raphael W., 2011, “Bank of Japan's Monetary Easing Measures: Are they Powerful and Comprehensive?," IMF Working Paper 11/264 (Washington: International Monetary Fund).

Segoviano, Miguel A., and Charles Goodhart, 2009, "Banking Stability Measures," IMF Working Paper No. 09/4 (Washington: International Monetary Fund).

Segoviano, Miguel A., 2006, "Portfolio Credit Risk and Macroeconomic Shocks:

Applications to Stress Testing Under Data-Restricted Environments," IMF Working Paper No. 06/283 (Washington: International Monetary Fund).

Tokuoka, Kiichi, 2010, “The Outlook for Financing Japan's Public Debt,” IMF Working Paper 10/19 (Washington: International Monetary Fund).

Ueda, Kauzo, 2011, "Japan's Deflation and the Bank of Japan's Experience with Nontraditional Monetary Policy," CARF F-Series CARF-F-235, Center for Advanced Research in Finance, The University of Tokyo. 